\title{
LETTER
}

\section{Algorithm-based management of bleeding in patients with extracorporeal membrane oxygenation}

\author{
David Faraoni*1 and Jerrold H Levy ${ }^{2}$ \\ See related research by Repressé et al., http://ccforum.com/content/17/2/R55
}

We read with interest the paper published by Repressé and colleagues [1]. Coagulation management is a challenge during extracorporeal membrane oxygenation (ECMO) due to complex hemostatic and inflammatory responses associated with the underlying conditions that include infection, sepsis, surgery, and/or traumatic injury [2]. Repressé and colleagues present the first algorithmbased approach to bleeding in ECMO patients. However, additional perspectives are important to consider.

First, activated partial thromboplastin time or antiactivated factor $\mathrm{X}$ monitoring are routinely used to monitor heparin therapy in ECMO patients, despite intraindividual and inter-individual variability [3]. Rotational thromboelastometry $\left(\mathrm{ROTEM}^{\circ} ; \mathrm{TEM}^{\circ}\right.$ International $\mathrm{GmbH}$, Munich, Germany) is also increasingly used in the ICU to rapidly assess the coagulation status, including clotting factors, fibrinogen levels, and whole blood clotting [4]. Moreover, this test also facilitates fibrinolytic pathway evaluation, which cannot be easily explored by routine laboratory tests. We believe ROTEM ${ }^{\circ}$ could be used to design an algorithm-based approach to bleeding in ECMO patients and follow fibrinogen consumption associated with hyperfibrinolysis, an important cause of bleeding. For this reason, anti-fibrinolytic agents should be considered in the multimodal approach (Figure 1), an important point the authors omitted in their algorithm.

Second, adverse events including 32\% venous thrombosis and a $2.5 \%$ incidence of fatal pulmonary embolism have already been reported in ECMO patients [5]. In another series, Combes and colleagues reported a 10\% incidence of femoral vein and $7 \%$ incidence vena cava thrombosis [6]. Recombinant activated factor VII is associated with thromboembolic events [7] and should

\footnotetext{
*Correspondence: davidfaraoni@icloud.com

'Department of Anesthesiology, Queen Fabiola Children's University Hospital, 15 Avenue JJ Croca, B-1020 Brussels, Belgium

Full list of author information is available at the end of the article
}

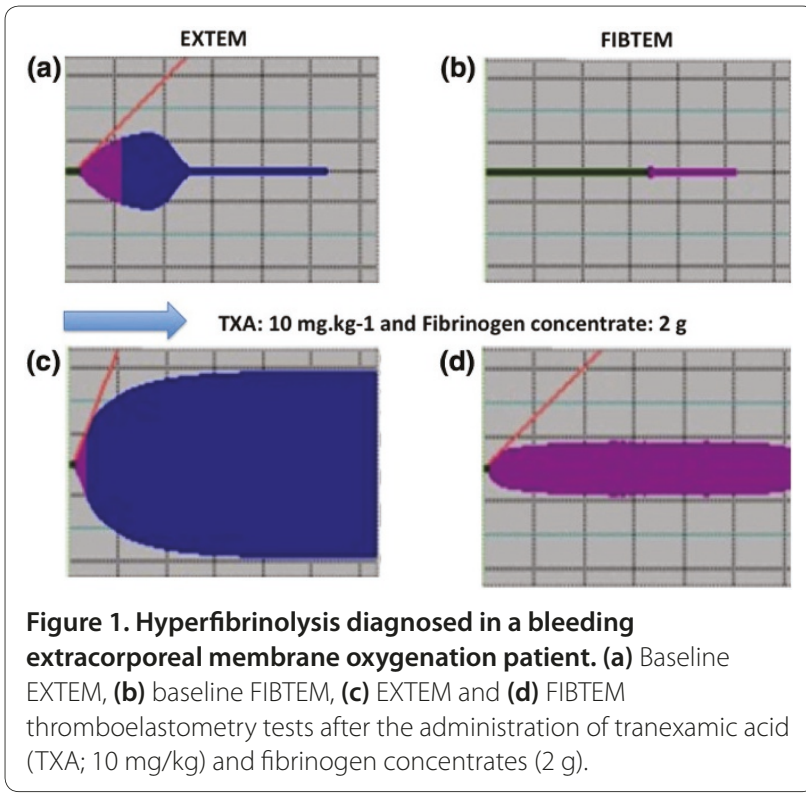

be used with caution until additional data help us evaluate the benefit-to-risk administration in bleeding ECMO patients.

\section{Abbreviations \\ ECMO, extracorporeal membrane oxygenation; ROTEM, rotational \\ thromboelastometry.}

\section{Competing interests}

The authors declare that they have no competing interests.

\section{Author details}

'Department of Anesthesiology, Queen Fabiola Children's University Hospital, 15 Avenue JJ Crocq, B-1020 Brussels, Belgium. ${ }^{2}$ Department of Anesthesiology and Intensive Care, Duke University School of Medicine, DUMC 3094, Durham, NC 27710, USA.

\section{Published: 8 May 2013}

\section{References}

1. Repressé X, Au SM, Brechot N, Trouillet J, Leprince P, Chastre J, Combes A, Luyt CE: Recombinant factor VIla for uncontrollable bleeding in patients with extracorporeal membrane oxygenation: report on 15 cases and literature review. Crit Care 2013, 17:R55. 
2. Peek GJ, Firmin RK: The inflammatory and coagulative response to prolonged extracorporeal membrane oxygenation. ASAIO J 1999, 45:250-263

3. Dempfle CE, Elmas E, Link A, Suvajac N, Liebe V, Janes J, Borggrefe M: Endogenous plasma activated protein $\mathrm{C}$ levels and the effect of enoxaparin and drotrecogin alfa (activated) on markers of coagulation activation and fibrinolysis in pulmonary embolism. Crit Care 2011, 15:R23.

4. Bischof D: Thrombelastography in the surgical patient. Minerva Anestesiol 2010, 76:131-137.

5. Rastan AJ, Lachmann N, Walther T, Doll N, Gradistanac T, Gommert JF, Lehmann S, Wittekind C, Mohr FW: Autopsy findings in patients on postcardiotomy extracorporeal membrane oxygenation (ECMO). Int J Artif Organs 2006, 29:1121-1131.
6. Combes A, Leprince P, Luyt CE, Bonnet N, Trouillet IL, Leger P, Pavie A, Chastre $\mathrm{J}$ : Outcomes and long-term quality-of-life of patients supported by extracorporeal membrane oxygenation for refractory cardiogenic shock. Critl Care Med 2008, 36:1404-1411.

7. Levy JH, Faraoni D, Sniecinski RM: Perioperative coagulation management in the intensive care unit. Curr Opin Anaesthesiol 2013, 26:65-70.

doi:10.1186/cc12682

Cite this article as: Faraoni D, Levy JH: Algorithm-based management of bleeding in patients with extracorporeal membrane oxygenation. Critical Care 2013, 17:432. 
EXTEM

(a)

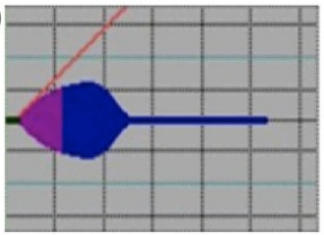

FIBTEM

(b)

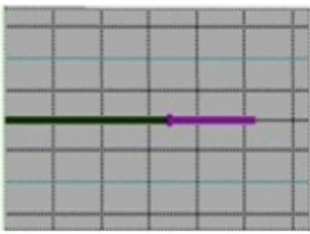

\section{TXA: $10 \mathrm{mg} . \mathrm{kg}-1$ and Fibrinogen concentrate: $\mathbf{2 g}$}

(c)

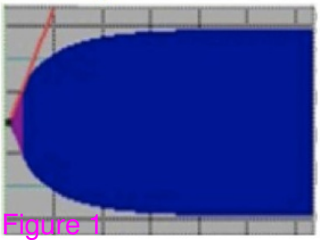

(d)

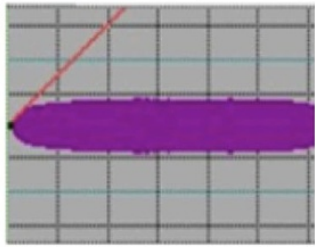

